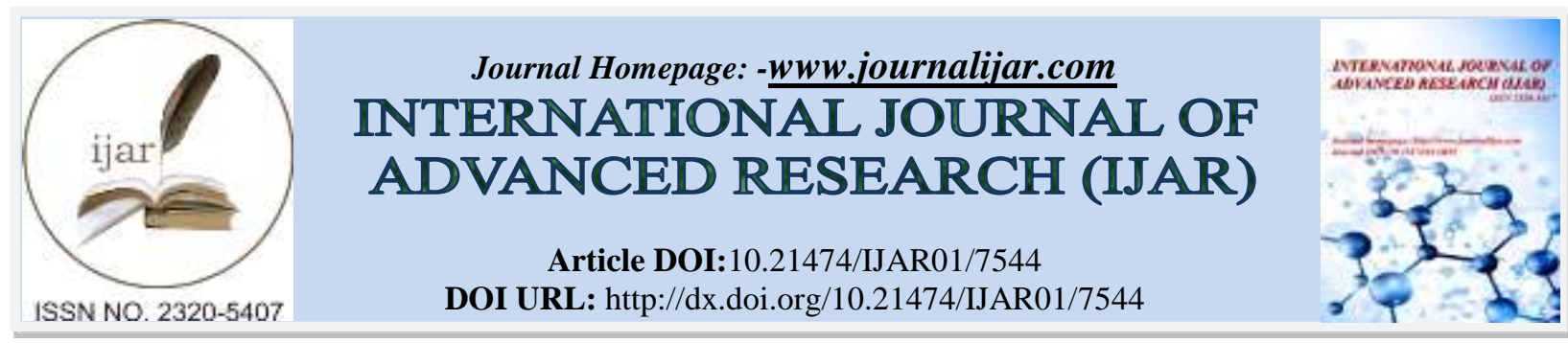

RESEARCH ARTICLE

\title{
THE EFFECT OF PARTICIPATION AND GOAL CLARITY BUDGET TO PERFORMANCE APPARATUS WITH TORAJA CULTURAL AS A MODERATING VARIABLE.
}

\author{
Manggalawati Tande Bura ${ }^{1}$, Andi Kusumawati ${ }^{2}$ and Arifuddin ${ }^{3}$. \\ 1. Magister of Accounting, Hasanuddin University, Indonesia. \\ 2. PerintisKemerdekaan KM 10, Makassar 90245, Indonesia. \\ 3. Accounting Departement, Faculty of Economic and Business, Hasanuddin University.
}

\section{Manuscript Info}

Manuscript History

Received: 12 June 2018

Final Accepted: 14 July 2018

Published: August 2018

Keywords:

participation, goal clarity budget, Toraja

cultural, performance apparatus

\begin{abstract}
This study aims to examine the direct influence to budgetary participation and clarity of budget targets on the performance of the apparatus as well as to examine the influence of Toraja culture as variabel that strengthens the relationship between budgetary participation and clarity of budget targets on the performance of Tana Toraja district government officials. This study used a quantitative approach. Objects studied were all employees in echelon III and IV at each OPD (Organization of Regional Devices). Data were obtained using survey method. The research instrument was in the form of questionnaire. The sample of research was 125 respondents by using purposive sampling method. Data were analyzed by using Moderated Regression Analysis Method that was processed by using Statistical Package for the social sciences (SPSS v.22). The result show that budgetary participation and clarity of budget targets significantly affect the performance of the apparatus. Toraja culture moderates the influences of budgetary participation and budget targets on apparatus performance.
\end{abstract}

Copy Right, IJAR, 2018,. All rights reserved.

\section{Introduction:-}

Regions based on Law Number 32 of 2004 concerning Regional Government are the rights, authorities and obligations of regional autonomy to regulate and manage their own government affairs and the interests of local communities in accordance with the laws and regulations. Law Number 32 of 2004 which has been changed to Law Number 23 of 2014 due to the rules regarding local government that are no longer in line with the development of the state, state administration, and the demands of the implementation of the regional government and then amended again into Law Number 9 of 2015 concerning Local Governments because there are some that need to be made changes regarding the provisions of duties and authority.

The delegation of authority from the central government to the regional government, known as decentralization, has made the regional government manage its own government affairs (Agusti 2012). Decentralization has caused the regional government to regulate overall the management of its regional revenues and expenditures. Regional Revenue and Expenditure Budget (APBD) which is used as a tool to determine the amount of income and expenditure, tools for decision making and development planning, as well as expenditure authority tools in the future. 
Regional income can be derived from Regional Original Revenue (PAD), balance funds and other legal income. PAD is one of the regional expenditure sources. If PAD increases, the funds owned by the regional government will be higher and the level of regional independence will increase as well, so that the Regional Government will take the initiative to further explore regional potentials and increase economic growth (Devita et al, 2014). This shows a strong indication, that if regional PAD increases, the ability of regions to make capital expenditure will also experience an increase.

Budget is an important part of both the public and private sectors. In the public sector the budget that has been prepared and agreed upon according to the later needs will be published to the public, while the private sector is part of company secrets that are closed to the public. The process of budgeting in the public sector involves the participation of many parties because in the end the results of this budgeting will be evaluated and will be seen how the performance of government officials in managing their regional budgets (Nordiawan and Hertianti 2010).

The budgeting process which is carried out from the planning, preparation and implementation stages in carrying out its duties and functions to realize the stated goals that are reported and accountable to the public in the form of budget reporting is a form of government accountability in carrying out the expected government system (Bastian 2010) . In the public sector, all parties, both the government and the community, should both have an agreement in budget management so that the agreed budget will be realized in accordance with its objectives.

The budget preparation process in the public sector begins with the formulation of policies from each Regional Device Organization (OPD) and then the preparation of work plans and discussions and the determination of the APBD. At each of these stages the role of the apparatus in budgeting participation is very influential so that later it will improve their performance as government officials (Hasbiah, 2017).

There is also a budget preparation that is Top Down and some are Bottom Up, namely the budget is prepared based on the aspirations of the community and then used as input for the government to compile a budget (Brownell 1982). This activity is usually called Musrembang where the government goes down directly to find out what is the needs and problems of the community.

Planning and budgeting carried out by the apparatus is seen based on the capability of the apparatus in carrying out managerial tasks which include planning, coordination, investigation, supervision, staffing, negotiation and representation (Mahoney in Leach-Lopez et al, 2007).

Managerial performance of regional work units is an illustration of the level of achievement of targets or objectives that have been previously determined. To be able to find out whether the performance is effective or ineffective, an evaluation of the budget must be carried out (Bastian, 2010). Meanwhile, according to Nina (2014) the performance of government officials is a set of results achieved by local government officials who aim to assess a strategy through financial and non-financial measures. In performance there is an overview of the level of achievement of the implementation of an activity or program of wisdom in realizing the goals, objectives, mission and vision of an organization contained in the formulation of a strategic scheme of an organization.

Every government agency is obliged to prepare, compile and submit performance reports in writing, periodic and institutionalized (Kusumaningrum, 2010). This performance reporting is intended to communicate to what extent the performance of government agencies in a fiscal year is related to the process of achieving the goals and objectives of government agencies. The relevant government agencies must account for and explain the successes and failures of the level of performance achieved.

This performance reporting by government agencies is then outlined in the LAKIP document. LAKIP can be categorized as a periodic report, because it is at least compiled and submitted to interested parties once a year. In order to fulfill these objectives, it is necessary to regulate the principles in the preparation of LAKIP so that the prepared LAKIP is of high quality, so that it can be reported and accounted to stakeholders / stakeholders for the governance process. LAKIP as a document that contains a description of the realization of AKIP which is compiled and submitted systematically and institutionally in accordance with Decree No. LAN.239 / IX / 6/8/2003 of 2003 concerning Improvement of Guidelines for Preparing Government Institution Performance Accountability Reports (LAKIP). 
The results of the LAKIP evaluation of the local government of TanaToraja Regency in 2014 sd 2016 showed different results. In 2014 got the results of WDP (Fair with Exceptions), in 2015 got the results of the Disclaimer because of the findings of budget realization greater than those budgeted and in 2016 got the results of the WDP. This shows the performance achieved by the local TanaToraja District government in implementing its programs and activities. (Makassar news, 02/13/2018). The results of the LAKIP evaluation in 24 Regencies / Cities in South Sulawesi Province in 2016 showed that the local government of TanaToraja Regency was ranked 19th with the predicate $C$ of LAKIP evaluation value 41.01. This shows that the performance of local government officials in the planning, implementation, administration, reporting, accountability, and supervision of programs and activities against budget allocations is still low.

The phenomenon that occurs based on the data regarding the budget and the results of LAKIP which shows the achievement of performance, that there is still weak participation and clarity in the preparation of budgets to improve performance. In reality it is this different theory and practice that is the problem. Whereas based on the theory of goal setting that the higher the participation of the apparatus, it will facilitate decision making in preparing the budget and the higher the clarity of the budget target, the easier it will be in achieving the goals.

According to Locke's Theory Goal Setting (1998) that the more level of someone's participation in budgeting, there will be many ideas (thoughts) that will be obtained so that someone feels important and will also be responsible for what he does because it will improve the performance of someone.

Participation is a behavior, activity and work carried out by government officials during budgeting activities. Bangun (2009) argues in participation decision making as a joint process by two or more parties that has an impact on the maker and recipient of the decision. The advantage of participation in budgeting is that it can motivate subordinates to achieve targets, can spur moral improvement, initiative of line managers, effective information exchange between budget makers and implementers. Whereas the weaknesses in participation in budgeting are sometimes setting too high a standard, can cause a budget gap.

The clarity of a clear budgeting will also be easier to achieve the objectives explained by the Goal Setting Theory proposed by Locke (1998). This theory explains that the involvement of the apparatus in the preparation will also be very helpful with the clarity of the budget goals and what goals will be achieved.

The clarity of the budget target provides certainty to the executor of the budget to account for successes and failures while carrying out their duties to achieve the goals and objectives that have been set beforehand (Suhartono and Solichin, 2006). While the obscurity of budget targets will cause confusion, pressure, and dissatisfaction in work. The existence of a clear budget target, the budget maker will have sufficient information about the budget targets to be achieved rather than the lack of clarity of the budget target.

The fundamental thing in determining this study is the research on the influence of the participation of budget makers and the clarity of budget targets on the performance of local government officials has not been done a lot and there are differences in the results of research on the participation of budget makers and the clarity of budget targets in relation to the performance and differences in the results of research on budgetary participation and the clarity of budget targets on performance with local culture as moderating variables.

Research that uses the influence of other variables besides budgeting participation and the clarity of budget targets on performance is the moderator of organizational culture. Research shows that cultural variables as moderators have a significant influence on the relationship between budgetary participation and performance (Aziz et al., 2017; and Hasbiah, 2017) and the significant influence of cultural moderation on the relationship of clarity of budget targets with performance (Mangunjung, 2015). On the other hand, cultural variables as moderators have an insignificant influence on the relationship between budgetary participation and performance (Agusti, 2012) and the insignificant influence of cultural moderation on the relationship of clarity of budget targets with performance (Putra and Gunardi, 2016).

The role of employees or officers in budgeting is directly or indirectly influenced by cultural factors in improving performance. According to Hofstede (1983) that national culture is the values and beliefs that are manifested in the form of habits in a society. Then within the framework of the national culture is based on the assumption that 
humans throughout the world will be guided and directed by different attitudes, beliefs, morals, customs, and ethical standards.

Strong culture is shown by the values, norms, and beliefs that exist within an organization that are reflected in employee behavior. Culture is defined as a set of values, beliefs, understanding, and basic norms that underlie individuals within an organization (Sugiwardani, 2012). The local culture that is meant in this research is Toraja culture, where the Toraja people are very firm in their culture and preserve it to this day.

Toraja culture itself makes the community known to the world because of its uniqueness. Tongkonan culture is the cultural basis for Toraja people, especially in giving directions to follow good teachings. In Tongkonan there are values that respect each other, social values, and togetherness. The role of Tongkonan needs to be preserved because it is a unifying force for the Toraja community (Petrus, 2018).

The tradition that occurs in the Toraja community today is a culture that becomes a habit for them and does not rule out the possibility that they participated in the preparation of the budget. Culture is not only symbolic for the Toraja community but has become a tradition they believe in in their lives. In the budget preparation stage, culture is one of their factors in composing and managing the budget, in addition to being in accordance with government regulations, there is also the influence of the cultural values they believe that they apply in the preparation of the budget.

The purpose of this study was to determine the effect of budget participation and clarity of budget targets on the performance of TanaToraja District government officials.

\section{Literature Review:-}

\subsection{Goal Setting Theory;-}

The theory of goal setting was first proposed by Locke (1998) which is one part of motivation theory. Goal setting theory is based on evidence that assumes that goals (ideas about the future; desired conditions) play an important role in acting. Goal-setting theory is an individual model that wants to have goals, choose goals and be motivated to achieve goals.

Locke's goal setting theory says that the conscious intentions and goals of the individual are the factors that determine the main behavior. Individual behavior will continue until the behavior reaches a higher level of performance. According to this theory, performance will depend on the level of difficulty of the goal, the detail of the goal, and one's commitment to the goal.

This theory also states that individual behavior is governed by one's ideas (thoughts) and intentions. Goals can be seen as goals or levels of work that individuals want to achieve. If an individual is committed to achieving his goals, this will affect his actions and affect the consequences of his performance. This theory also explains that setting goals that are challenging (difficult) and measurable results will be able to improve work performance (performance), which is followed by skills and job skills. Based on the description above, it is assumed that in order to achieve optimal performance there must be suitability of individual and organizational objectives. By using the goal setting theory approach, good employee performance in organizing public services is identified as the goal.

The theory of goal setting relates to the achievement of the performance of the apparatus with the existence of clear objectives so as to facilitate the preparation of the budget and also will maximize the performance in accordance with the goals of the organization. The clearer the goals set will be very helpful in the process until the expected results are in accordance with what is targeted.

The framework of thought developed in this study is based on concepts and theories as well as several empirical studies that have been proposed, the conceptual framework can be prepared as follows. 


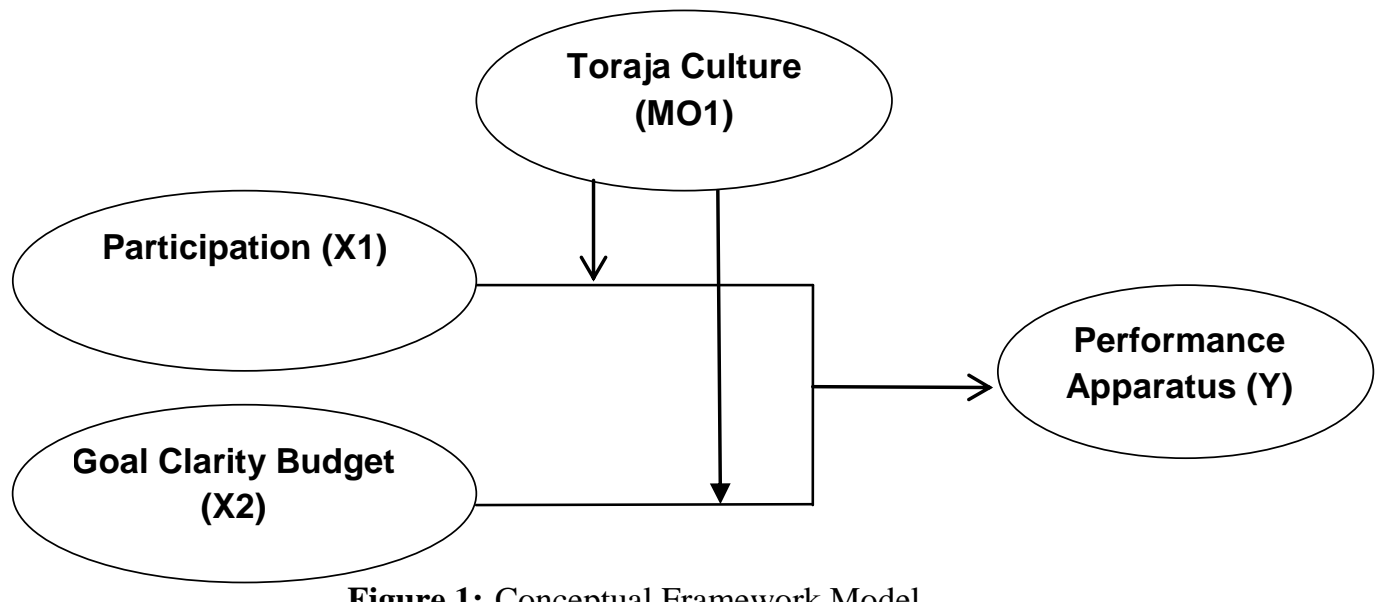

Figure 1:-Conceptual Framework Model

\section{Hypothesis Development:-}

3.1 Effect of Budget Participation on Apparatus Performance:-

Budget participation is the level of how far the individual's involvement and influence in determining and preparing the budget in the division or its part, both periodically and annually. Budget participation shows the extent to local government officials in understanding the budget by their work units and the influence of the objectives of their budget accountability centers. While the performance of Government officials is a system that aims to assist leaders in assessing the achievement of a strategy through financial and non-financial measures. Budgeting participation basically allows lower-level managers to consider how budgets are formed (Hansen and Mowen, 2000).

Hendra (2018) in the process of budgeting involves many superiors and subordinates producing good managerial performance. Similar results have also been found by Nurhalimah (2013), Azis, et al (2017), Aisyah, et al (2017) where budget participation has a positive effect on managerial performance. While the research conducted by Milani (1975) found that budgeting participation had no effect on managerial performance. Yusri's (2012) and Jannah (2015) study found that budgetary participation did not affect the performance of officials.

Based on inconsistencies in the results of existing research, this study was conducted again to examine the effect of budget participation on the performance of local government officials. The hypothesis proposed in this study are as follows:

\section{H1: Budget participation has a significant effect on apparatus performance}

\section{Effect of Budget Target Clarity on Apparatus Performance:-}

The clarity of budget targets will help employees achieve the expected performance, where by knowing the budget target, the level of performance can be achieved. The existence of a clear budget target, it will be easier to account for the success or failure of the implementation of organizational tasks in order to achieve the goals and objectives that have been set previously. Unclear budget targets will cause budget execution to be confused, not calm and not satisfied at work. This will cause the implementers of the budget budget not motivated to achieve the expected performance (Syafrial, 2009).

Research conducted by Kalsum and Wahyuningsih (2012) examined the effect of budget participation, clarity of budget objectives and budget evaluation on the performance of local government officials in the regional work unit of Bengkalis Regency. The results of this study indicate that budget participation, clarity of budget objectives and budget evaluation simultaneously have a significant effect on the performance of Bengkalis Regency government officials. Similar research results were also carried out by Fladimir (2013), Putra (2013), and Abdul Latif (2014) showed a significant influence between the clarity of budget targets on the performance of the apparatus. While Nurhalimah's research (2013), Amril (2014), Mangunjung (2015) and Nangoy, Sondakh, and Sabijono (2016) found the clarity of budget targets did not affect the performance of the apparatus.

Based on inconsistencies in the results of existing research, this study was conducted again to examine the effect of budget participation on the performance of local government officials. The hypothesis proposed in this study are as follows: 


\section{H2: The clarity of the budget target has a significant effect on the performance of the apparatus.}

3. Effect of Budget Participation on Apparatus Performance with Toraja Culture as Moderation Variables:Culture is the shared values and beliefs that characterize a person (Benny, 2013). Local culture is a culture that grows and develops and is owned and recognized by local ethnic communities. Local culture usually grows and develops in a particular tribal or regional community because of the inherited hereditary heritage. This regional culture will emerge when the population of a region has the same mindset and social life, so that it becomes a habit that distinguishes them from other populations.

Community cultural values that have been passed down from generation to generation and then until now still held by the surrounding community will reflect their behavior in their daily lives. Culture is the identity of society because it is a trust for them. In preparing the budget involving various parties, it is hoped that this culture will be a factor that will improve the performance of government officials. The achievement of these targets and the involvement of all parties in the preparation of the budget will motivate government officials to maximize their performance.

Hasbiah (2017) found a positive influence on the relationship of budget participation to the performance of the apparatus moderated by individual culture. Research based on the relationship, the following hypothesis can be formulated:

H3: Toraja culture moderates the influence of budget participation on the performance of government officials.

4. Effect of Budget Target Clarity on Apparatus Performance with Toraja Culture as Moderation Variables:The clarity of the budget target of the performance of an organizational work unit is considered good financially. A clear budget target will make it easier for the apparatus to develop budget targets. Furthermore, the budget targets that are prepared will be in accordance with the targets to be achieved by the local government, on the contrary if the lack of clarity of budget targets the apparatus will have little information about the success or failure of the implementation of the organization to achieve the goals and targets set beforehand. Therefore, with the existence of a clear budget target, it is expected that the local government apparatus in this case each OPD is able to improve its performance in accordance with the predetermined targets.

Culture is something that regulates so that humans can understand how they should act, act, and determine their attitude if they relate to other people. Strong culture will have a big influence on individual behavior. The relationship with the clarity of the budget target where the members involved in preparing the budget are expected to work carefully to plan the budget clearly and specifically so that later it will be easier to account for it. So that later it will also affect the performance of the apparatus in preparing a clear budget that is in accordance with the goals of the organization.

Individual culture has an influence on behavior, motivation and the workings of leaders and subordinates to achieve organizational performance (Holmes and Marsden, 1996). This research was conducted by Mangunjung (2015) to find the siri'napacce culture to moderate the relationship between the clarity of budget targets on apparatus performance. Based on the results of research related to culture, it was found that the cultural dimension has an influence on budget clarity in improving performance, based on the relationship, a hypothesis can be formulated as follows:

H4: Toraja culture moderates the influence of clarity of budget targets on apparatus performance

\section{Research Methodology:-}

\subsection{Research Model:-}

This study uses a quantitative approach, and based on its purpose this research is explanative, namely to get an explanation of the relationship (causality) between variables, through hypothesis testing.

\section{Population and Sample:-}

The population of this study is all OPD within the scope of TanaToraja Regency. The sample of this study was 125 respondents in each OPD. The sampling technique uses purposive sampling, which is the sampling technique that is determined by certain considerations. The consideration that is determined in this study in sampling is civil servants (PNS) who work in the scope of the Regional Government of TanaToraja Regency which is directly related to the preparation of work programs and budgets consisting of echelon III and echelon IV. 


\section{Method of Collecting Data:-}

This study uses data collection methods with field surveys, namely by distributing questionnaires to apparatus of local government officials. Questionnaires distributed will provide an explanation of the respondents related to this research.

\section{Data Analysis Method:-}

This study uses a moderation regression model, using the Statistical Package for Social Science (SPSS) application which will provide clear results using validity and reliability testing, data normality testing and classical assumption tests.

\section{Data Quality Test:- \\ Validity test:-}

Determination of the validity of the questionnaire question is determined through the magnitude of the correlation coefficient, namely: if $r$ count is positive and $r$ count $>r$ table, then the score of the questionnaire items is valid, and vice versa if $r$ counts negative and $r$ counts $<r$ table, then the score of the questionnaire questions is not valid (Ghozali, 2016).

\section{Reliability Test:-}

Reliability is actually a tool to measure a questionnaire which is an indicator of variables or constructs. A questionnaire is said to be reliable or reliable if someone's answer to the statement is consistent or stable over time. The test was carried out using the Cronbach alpha technique. Where an instrument can be said to be reliable if it has a reliability or alpha coefficient of: (a) $<0.6$ not reliable, (b) $0.6-0.7$ acceptable, (c) $0.7-0.8$ good, and (d) $>0.8$ is very good (Ghozali 2016).

\section{Classic Assumption Test:-}

Before the data was analyzed further using multiple regression analysis, the first classical assumption was carried out consisting of: normality test, multicollinearity test, and heteroscedasticity test.

\section{Normality Test:-}

Data normality test used in this research is Kolmogorov - Smirnov test. The criteria for testing one sample using one-sided testing is by comparing probabilitias with certain significance, namely: Significant value or probability $<0.05$, then the data distribution is not normal. Significant value or probability $>0.05$ then the data distribution is normal. In addition to seeing the significance value of the Kolmogrof-Smirnof test, to see a data has a normal distribution it can be seen from the value of Zskewness and by looking at the graph.

\section{Multicollinearity Test:-}

Multicollinearity test aims to test whether the regression model is found or not correlation between independent variables (free). If there is a correlation between independent variables, there will be a problem of multicollinearity (Ghozali 2016). A good regression model must not cause multicollinearity problems. For this reason, multicollinearity test is needed for each independent variable, that is by looking at the tolerance value in the multicollinearity assessment output which does not show the Tolerance value $<0.10$ will give the fact that there is no multicollinearity problem.

\section{Heterocedasticity test:-}

This test aims to see whether in the regression model there is a variance inequality from residual one observation to another observation. If the variance from residual one observation to another observation remains, it is called homokedasticity, if different is called hetroskedastisitas (Ghozali 2016).

\section{Data Analysis Model:-}

The model used is a multiple linear regression research model and multilevel regression analysis with an interaction test approach, which is described below:

The model used in this study is presented in the following equation:

Hypothesis testing:-

$$
\text { Model: } \mathrm{Y}=\alpha+\beta 1 \mathrm{X} 1+\beta 2 \mathrm{X} 2+\beta 3 \mathrm{X} 1 . \mathrm{X} 3+\beta 4 \mathrm{X} 2 . \mathrm{X} 3+\mathrm{e}
$$

Based on the results of the analysis, the correlation coefficient between budget participation (X1) and apparatus performance $(\mathrm{Y})$ is 0.746 with a $\mathrm{p}$-value of 0.000 . Because the p-value $<0.050$ identifies that budget participation 
(X1) is significant to the performance of the apparatus (Y). Because the coefficient is positive, it identifies a unidirectional relationship. This means that the higher the budget participation value (X1), the higher the performance value of the apparatus (Y) will result.

Based on the results of the analysis, the relationship coefficient between the clarity of the budget target (X2) and the performance of the apparatus $(\mathrm{Y})$ is 0.255 with a $\mathrm{p}$-value of 0.003 . Because the p-value $<0.500$ identifies that the clarity of the budget target (X2) is significant to the performance of the apparatus (Y). Because the coefficient is positive, it identifies a unidirectional relationship. This means that the higher the clarity of the budget target (X2), the higher the performance value of the apparatus $(\mathrm{Y})$ will be.

Regression analysis results obtained an interaction coefficient of 0.562, and a t-hit of 2.659, and a p-value of 0.009. Because the t-hit value $>1,979$. And the $\mathrm{p}$-value $<0.050$ so that the Toraja culture (MO1) is a moderator variable between the effect of budget participation (X1) on the performance of the apparatus (Y).

Regression analysis results obtained an interaction coefficient of 1,179, and a t-hit of 2,067, and a p-value of 0,041. Because the t-hit value $>1,979$. As well as the p-value $<0.050$ so that the Toraja culture (MO1) is a moderator variable between the influence of the clarity of the budget target (X2) on the performance of the apparatus (Y).

\section{Result:-}

Goal Setting Theory provides an explanation of behaviors that determine a person to be able to decide what should be done to achieve the goals to be achieved. Budget preparation, for example, requires responsibility later when it is finished so that it requires the involvement of participants who have the ability to be able to manage and account for it later. Budgeting participation basically allows lower level managers to consider how budgets are formed (Hansen and Mowen, 2000). The results of this study prove that employees who participate in budgeting can influence their responsibilities so as to improve the achievement of the objectives of the workplace organization.

The theory of goal setting (Goal Setting Theory) relates to the achievement of the performance of the apparatus with the existence of clear objectives so as to facilitate the preparation of the budget and also will maximize performance in accordance with the goals of the organization. The clearer the goals set will be very helpful in the process until the expected results are in accordance with what is targeted.

Research on budgetary participation and the clarity of budget targets on the performance of local government officials have not been widely carried out. Most of the research (Kenis, 1979; Brownell and Mc.Innes, 1986; Kewo, 2014) looked at the influence of the participation of budget compilers and the clarity of budget targets on managerial performance.

Culture can be interpreted as a set of values, beliefs, understanding, and basic norms that underlie individuals within an organization (Sugiwardani, 2012). Strong culture is shown by the values, norms, and beliefs that are reflected in an organization that will improve performance. With a strong individual culture that has a positive impact on an organization, a strong culture can function as someone's guidance formally into various organizational rules and regulations.

\section{Conclusions and Recommendations:-}

The higher participation of the apparatus in preparing the budget will improve the performance of the apparatus. In accordance with the Goal Setting Theory in terms of budget preparation the involvement of all parties in budgeting is very important which makes it easier because all parties provide opinions and input regarding budgeting, so that what has been decided is waiting in accordance with the objectives to be achieved .

The clearer the budget target will be to improve the performance of the apparatus. The theory of goal setting explains the clear objectives that will affect performance. The achievement of goals depends on the level of difficulty, the clarity of the goals to be achieved and the commitment of a person to achieving the goals. Clarity of budget targets that are increasingly clear will make it easier for parties involved in the preparation because they are more specific so that they will be easily accountable. 
Increasingly implementing the value of Toraja culture, influencing the increasing influence of budgetary participation on the performance of the apparatus. Strong culture can be a motivation to improve performance. Culture provides an understanding of participating in an organizational environment by giving opinions and considerations that will be an accountable decision.

Increasingly implementing the value of Toraja culture, influencing the increasing influence of clarity of budget targets on the performance of the apparatus. A strong culture can also influence the behavior of a person at work. In relation to the clarity of budget targets, it can be explained that if someone clearly understands what he is doing, it will make it easier to achieve the goals of the organization and will also affect its performance.

Based on the conclusions of the study, several recommendations were recommended to the next research, as follows: The Tana Toraja District Government pays more attention to the involvement of the parties in participating in the preparation of the budget, the clarity of budget targets, and the influence of the better Toraja culture that can improve the performance of the apparatus. A strong Toraja culture that is characteristic of the Toraja community needs for the government to continue to cultivate what is the value and beliefs of the Toraja people, because this can also be one of the PAD for the Tana Toraja District government. And further research should consider adding other variables to find a model for improving the performance of government officials in Tana Toraja Regency.

\section{References:-}

1. Agusti, Restu. 2012. The Influence of Budget Participation Participation on the Performance of Regional Government Apparatuses with Moderated by Variables of Decentralization and Organizational Culture (Case Study on Bengkalis Regency Government). Journal.Riau University.

2. AisyahSitiNur, Sutisno, Erwin Saraswati. 2017. The Effect of Participatory Budgets on the Performance of School (Studies in SMK Sumbawa). Journal of Accounting and Business Education, 1 (2), March 2017.

3. Amril, VonnyNofisa. 2014. The Influence of Public Accountability, Participation in Budget Preparation and Clarity of Budget Goals on Managerial Performance of SKPD (Empirical Study on Regional Work Units in Sijunjung District). Scientific articles.Accounting Study Program, Faculty of Economics, University of Padang.

4. AzisFajriani, Arifuddin, KusumawatiAndi. 2017. Participation and Goal Clarity Budget to Performance Apparatus with Commitment and Cultural Organization as a Moderating Variable. World Journal of Social Sciences.Vol. 7.No. 2.September 2017 Issue. Pp. 24 - 37.

5. Bangun, Andarias. 2009. Effect of Budget Preparation Participation, Clarity of Budget Objectives and Decentralization Structure on SKPD Performance with Internal Supervision as Moderating Variables (Case Study on the Government of Deli Serdang District. Thesis.Postgraduate School of North Sumatra University.

6. Bastian, Indra. 2010. Public Sector Accounting in Indonesia, Edition III. Erlangga, Jakarta.

7. Benni, Ashari. 2013. The Influence of Budgeting Participation on Managerial Performance with Organizational Culture and Organizational Structure as Moderation Variables. Padang State University.

8. Brownell, P. 1982. Participation in Budgeting Process When it Works and When it Does not. Journal of Accounting Literature.Vol. 1 p124-153.

9. DevitaAndri, Delis Arman, and Junaidi. 2014. Influence of Regional Original Revenue, General Allocation Funds and Population Amounts on District / City Spending in Jambi Province. Journal of Regional Financing and Development Perspectives Vol 2 No October 2-December 2014.

10. Fladimir, Edwin. 2015. Effect of Participation in Budget Preparation, Clarity of Budget Objectives, and Public Accountability on the Performance of Local Government Officials. Journal.Atma Jaya University Yogyakarta.

11. Ghozali, Imam. 2016. Multivariete analysis application with the IBM SPSS 23. program of the Diponegoro University Publishing Agency.

12. Hasbiah. 2017. Effect of Budget Target Participation and Clarity on Apparatus Performance with Individual Environmental and Cultural Uncertainty as Moderation Variables. Thesis.Hasanuddin University Makassar.

13. Hendra, Joni. 2018. Effect of Participation in Budgeting and Managerial Roles of Regional Financial Managers on Local Government Performance (Empirical Study on Probolinggo District Government). Scientific Journal of Accounting, Finance and Tax Sciences. Volume 2, Number 1, January 2018.

14. Hofstede, G: 1983, 'The Cultural Relativity of the Quality of Life Concept', Academy of Management Review 9 (3), 389-398.

15. Holmes, Scott and Mersden, Stephen. 1996. An Exploration of the Espoused Organizational Culture of Public Accounting Firm. Accounting Horizons, Vol 10, Number 3 September, pp. 26-53. 
16. Indrawan. February 13, 2018. "Evaluation of SAKIP, Makassar is the Highest in South Sulawesi". https://www.kabarmakassar.com/posts/view/354/ Evalu-sakip-makassar-tertinggi-di-sulsel.html. Retrieved 23 February 2018 at 7:00 p.m.

17. Kalsum and Wahyuningsih. 2015. Effect of Budget Participation, Clarity of Budget Objectives on Performance of Local Government Officials in Bengkalis Regency SKPD. Journal.Riau Islamic University.

18. Kenis. 1979. Effect of Goal Characteristic Budgetary on Managerial Attitude and Performance. The Accounting Review LIV (4). 707-721.

19. Kewo, Cecilia Lelly. 2014. The Effect of Participative Budgeting, Budget Goal Clarity and Internal Control Implementation on Managerial Performance. Research Journal of Finance and Accounting.ISSN 2222-1697 (Paper) ISSN 2222-2847 (Online).Vol.5, No.12.

20. Kusumaningrum, Indraswari. 2010. Effect of Budget Target Clarity, Accounting Control and Reporting System on the Performance Accountability of Central Java Provincial Government Agencies. Thesis.Diponegoro University.

21. Latif, Abdul. 2014. Effect of Budget Participation, Clarity of Objectives and Evaluation on the Performance of Gorontalo District Government Officials. Al-Buhuts Journal. Vol. 10 No.1.77-90.

22. Locke, E. A. 1968. Toward the Theory of Task Motivation and Incentives Organizational Behavior and Human Performance, 3, 157-189.

23. Mahoney, T.A. T.H. Jardee and S, J. Caroll. 1963. Development of Managerial Performance: A Research Approach. Southwestern Publishing, Co. Cincinati, Ohio.

24. Mangunjung, Cahyadi 2015.The Effect of Participation and Clarity of Budget Objectives on the Performance of Regional Apparatuses with $\mathrm{Na}$ Pacce'sSiri 'Culture as Moderation Variables.Thesis.Hasanuddin University Makassar.

25. Milani, K. 1975. The relationship of participation in budget setting to industrial supervisor attitude performance: A. Field Study. Accounting Review.April, p.274-284.

26. Nangoy Nikita Angelita Maria, Sondakh Julie, SabijonoHarijanto. 2012. Effect of Budget Target Clarity and Budget Participation on the Performance of Manado City Government Officials. Journal.Sam Ratulangi State University Manado.

27. Nina, Gina. 2014. Effect of Budget Purpose Characteristics and Procedural Justice on the Performance of Local Government Officials. Journal.Padang State University.

28. Nordiawan, Deddy and Hertianti, Ayuningtyas, 2010. Public Sector Accounting.SalembaEmpat.

29. Nurhalimah. 2013. Effect of budget participation and clarity of budget targets on the performance of regional apparatus in the Aceh government. Accounting journal.ISSN 2302-0164 pp.27-36.

30. Petrus Simon interview. 2018. "Toraja Culture". Makassar.

31. Putra, Deki. 2013. The Influence of Public Accountability and Clarity of Budget Objectives on Managerial Performance of Regional Work Units. Journal.Padang State University.

32. Putra and Gunardi. 2016. Paternalistic Cultural Influence and Organizational Commitment on Budgetary Goal Characteristics Relations with Managerial Performance. Journal.Mahasaraswati University Denpasar.

33. Sugiwardani, Resti. 2012. Analysis of the Effect of Budget Participation, Asymmetric Information, Culture and Organizational Commitment to Budgetary Slack. Scientific articles.STIE Perbanas Surabaya.

34. Suhartono, Erhmann and MochammadSolichin. 2006. "Effect of Budget Target Clarity on Budgetary Slack of Local Government Agencies with Organizational Commitment as Moderating". National Accounting IX Symposium, Padang August 23-26, 2006.

35. Syafrial. 2009. Effect of Accuracy of Budget Preparation Schedule, Clarity of Budget Objectives and Participation of Budget Preparation on Managerial Performance of SKPD AtSarolangun District Government. Thesis.University of North Sumatra Postgraduate School.

36. Yusri, Hazmi. 2012. Effect of Budget Participation on the Performance of Regional Government Apparatus, through Organizational Commitment and JRI as Intervening Variables of Lhokseumawe City Government. Journal.Lhokseumawe State Polytechnic. 